\title{
Increased tissue expression and activity of cGMP-dependent protein kinase I in ANP-receptor (GC-A) - deficient mice Ana Kilic ${ }^{1}$, Sevdalina Yurukova ${ }^{1}$, Stepan Gambaryan², Thomas Renné2, Ulrich Walter ${ }^{2}$, Melanie Voss ${ }^{1}$, Wolfgang Dostmann ${ }^{4}$ and Michaela Kuhn ${ }^{* 1,3}$
}

\author{
Address: ${ }^{1}$ Institute of Pharmacology and Toxicology, University of Münster, Germany, ${ }^{2}$ Institute of Clinical Biochemistry and Pathobiochemistry, \\ University of Münster, Germany, ${ }^{3}$ Institute of Physiology, University of Würzburg, Germany and ${ }^{4}$ Department of Pharmacology, University of \\ Vermont, USA \\ Email: Michaela Kuhn* - kilicana@uni-muenster.de \\ * Corresponding author
}

from 2nd International Conference of cGMP Generators, Effectors and Therapeutic Implications

Potsdam, Germany, 10-12 June, 2005

Published: 16 June 2005

BMC Pharmacology 2005, 5(SuppI I):P25 doi:I0.1I86/I47I-22I0-5-SI-P25

\section{Background}

In many tissues, a key mediator of cGMP signaling is cGMP-dependent protein kinase I (PKG I). In vitro and in vivo studies have shown that cGMP may not only regulate the kinase activity but also the expression levels of PKG I. Thus, chronic exposure of smooth muscle cells to high levels of NO or NO donors, via increased cellular cGMP, suppresses PKG I expression, which may partly explain the phenomenon of $\mathrm{NO}$ and/or nitrate tolerance. However, it is not known whether the opposite situation, namely a reduction in cellular cGMP levels, can increase PKG I expression. To investigate this question, we examined the expression and activity of PKG I in different tissues of mice with genetic deletion of guanylyl cyclase-A (GC-A $\mathrm{KO}$ ), an in vivo model of reduced cGMP formation in many different cell types.

\section{Methods}

The cyclic nucleotide (cGMP) contents of whole tissue homogenates were determined with a specific radioimmunoassay. Expression levels of PKG I, as well as phosphorylation of two specific target proteins, the sarcoplasmic reticulum (SR) regulatory protein phospholamban (PLB) as well as VASP (vasodilator-stimulated phosphoprotein), were studied by Western blot analysis and real-time RT-PCR (PKG I). Last, to evaluate possible biological consequences, the role of PKG I in the modulation of cardiomyocyte $\mathrm{Ca}^{2+}$ transients was studied in isolated, electrically stimulated $(0.5 \mathrm{~Hz})$ ventricular cardiomyocytes using the fluorescent dye indo-1AM.

\section{Results}

cGMP levels were reduced in the hearts, kidneys and aorta of GC-A KO mice, while there were no differences in pulmonary cGMP contents. Quantitative real-time RT-PCR showed no differences in PKG I mRNA expression levels between tissues from GC-A KO and wild-type (WT) mice. In contrast, Western blot analyses revealed increased protein expression of PKG I in heart, lung, kidney and aorta of GC-A KO mice. To determine endogenous kinase activity levels we measured PKG I-dependent phosphorylation of cardiac PLB (at $\operatorname{Ser}_{16}$ ) and of renal and pulmonary VASP (at the PKGI - specific site Ser $_{239}$ ). PLB phosphorylation was increased by 2-fold in GC-A KO hearts. VASP phosphorylation was increased by 1.85 -fold in lungs and by 1.92 -fold in renal papilas of GC-A KO as compared to WT mice.

Last, because increased expression and activity of PKG I, leading to enhanced PLB phosphorylation, may affect SERCA2A activity and thereby SR calcium handling in GCA KO cardiomyocytes, we investigated the impact of the observed changes on cardiomyocyte calcium handling. GC-A KO cardiomyocytes showed increased systolic $\mathrm{Ca}^{2+}{ }_{\mathrm{i}}$ levels (Indo 1 ratio $495 \mathrm{~nm} / 405 \mathrm{~nm}$ : $1.64 \pm 0.04$ in GC-A $\mathrm{KO}$ vs. $1.56 \pm 0.04$ in WT mice) whereas diastolic $\mathrm{Ca}^{2+}{ }_{\mathrm{i}} \mathrm{lev}-$ els were not different between genotypes $(1.42 \pm 0.01$ vs. $1.42 \pm 0.02)$. Selective inhibition of PKG I with the membrane-permeant peptide inhibitor DT-2 (5 $\mu \mathrm{M})$ had no influence on systolic $\mathrm{Ca}^{2+}$ levels in wild-type cardiomyocytes but caused a significant decrease in systolic $\mathrm{Ca}^{2+} \mathrm{lev}-$ 
els in GC-A KO cardiomyocytes $(1.6 \pm 0.03$ vs. $1.55 \pm$ 0.04; $\mathrm{P}<0.05)$.

\section{Conclusion}

Our results demonstrate that systemic deletion of the GCA receptor, causing a chronic depletion of cGMP within many cell types, may cause an increase in PKG I expression. Notably, these changes in protein levels occurred in the absence of changes in mRNA expression, suggesting either increased synthesis or diminished degradation of PKG I. The observation that cGMP levels in lungs were not changed, while protein expression levels of PKG I were increased deserves further investigation. Last, our study reveals a previously unappreciated function of cardiac PKG I in the regulation of PLB phosphorylation and thereby in SR calcium handling.

Publish with Bio Med Central and every scientist can read your work free of charge

"BioMed Central will be the most significant development for disseminating the results of biomedical research in our lifetime. " Sir Paul Nurse, Cancer Research UK

Your research papers will be:

- available free of charge to the entire biomedical community

- peer reviewed and published immediately upon acceptance

- cited in PubMed and archived on PubMed Central

- yours - you keep the copyright

Submit your manuscript here:

http://www.biomedcentral.com/info/publishing_adv.asp 